\title{
Synthesis of 1-ethyl-2-methyl-3-arylindanes. Stereochemistry of five-membered ring formation
}

\author{
Elba Alesso, ${ }^{\text {a }}$ Rosario Torviso, ${ }^{\text {a Beatriz Lantaño, }}$ Magali Erlich, \\ Liliana M. Finkielsztein, ${ }^{a}$ Graciela Moltrasio, ${ }^{* a}{ }^{a}$ osé M. Aguirre, ${ }^{b}$ and Ernesto Brunet ${ }^{c}$ \\ ${ }^{a}$ Departamento de Química Orgánica, Facultad de Farmacia y Bioquímica, Universidad de \\ Buenos Aires, Buenos Aires, Argentina. ${ }^{b}$ Departamento de Ciencias Básicas, Universidad \\ Nacional de Luján, Luján, Argentina. ${ }^{c}$ Departamento de Química Orgánica, Universidad \\ Autónoma de Madrid, Madrid, España \\ E-mail: gmoltra@ffyb.uba.ar
}

Dedicated to Professors Edmundo Rúveda and Roberto Rossi

(received 14 Jul 03; accepted 23 Sep 03; published on the web 29 Sep 03)

\begin{abstract}
A natural dimer of asarone and several analogues were obtained by acid-catalysed cyclodimerisation of styrenes and by formal [3+2] cycloaddition. A study of the influence of the aromatic ring substitution pattern on the stereochemistry of the reactions was carried out.
\end{abstract}

Keywords: Indanes, cyclodimerisation, formal [3+2] cycloaddition, stereochemistry

\section{Introduction}

A great number of compounds with an indane-like structure are found in nature. To this group belong those produced by biopolymerization of oxystyrenes and oxystilbenes, which have important biological properties such as anti-bacterial activity against Staphylococcus oxford and Escherichia coli, ${ }^{1}$ anti-fungal activity ${ }^{2}$ and anti-tumour in vitro activity by interacting with DNA. ${ }^{3}$ Among these compounds, a phenylindane, a dimer of asarone, may be found. The asarone $\mathbf{1}$ and its dimer $\mathbf{2}$ were originally isolated from the essential oil of Accorus calamus which is known as insect growth regulator, ${ }^{4}$ fungicide, insecticide, ${ }^{5}$ sedative and hypothermic agent. ${ }^{6}$

The structure of 4,5,7-trimethoxy-1-ethyl-2-methyl-3-(2,4,5-trimethoxyphenyl) indane was assigned to the natural dimer of asarone $2{ }^{4}$ There are four possible diastereomers for this structure, namely $\alpha, \beta, \gamma$ and $\delta$ (Fig.1).

NMR studies, ${ }^{4}$ later confirmed by X-rays analysis, ${ }^{7}$ allowed the $\gamma$ configuration to be assigned to this natural dimer 2 . 


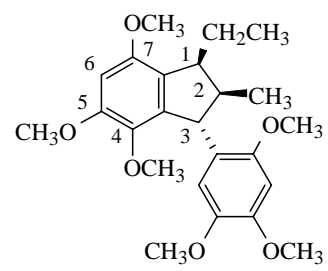

$\alpha$

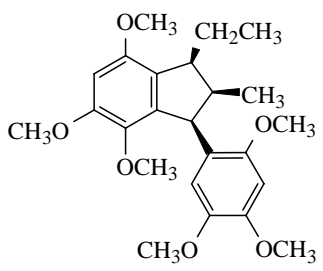

$\beta$

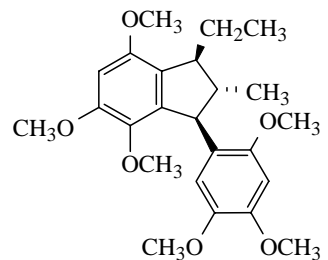

$\gamma(2)$

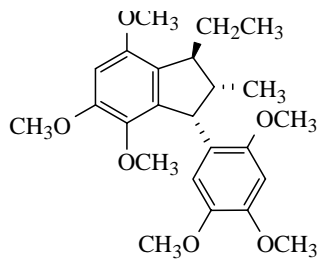

$\delta$

Figure 1

Dimerisation in mineral acid medium, ${ }^{8}$ with ethyl polyphosphate (EPP), ${ }^{9}$ or with silicasupported phosphotungstic or phosphomolybdic acid (TPA/S and MPA/S) ${ }^{10}$ of isohomogenol and isosafrole, produces mainly cyclodimers with $\alpha$ configuration, accompanied by the $\gamma$ stereoisomer in some cases as a minor product.

Such cyclodimer type may also be obtained by formal [3+2] cycloaddition of alcohol derived cation and alkene. ${ }^{11}$ By this pathway, dimer configuration proved to be preferably $\alpha$ and $\beta$, depending on the stereochemistry of the starting alkene. Unlike acid-catalysed dimerisation, this reaction renders dimers with dissimilar substituents in the aromatic rings. This is possible since formal [3+2] cycloaddition of alcohol and alkene is faster than alkene dimerisation. Our experience with this cycloaddition, ${ }^{12}$ shows that starting from benzhydrols and alkenes, the $\alpha$ diastereomer was preferably obtained, with the $\gamma$ diastereomer occasionally as the minor product.

The $\delta$ stereoisomer has only been obtained by means of stereodirected synthesis. ${ }^{13}$ It has been postulated that both, cyclodimerisation of styrenes in acid medium ${ }^{10}$ and formal $[3+2]$ cycloaddition, ${ }^{11}$ possess a common cationic intermediate (Scheme 1).
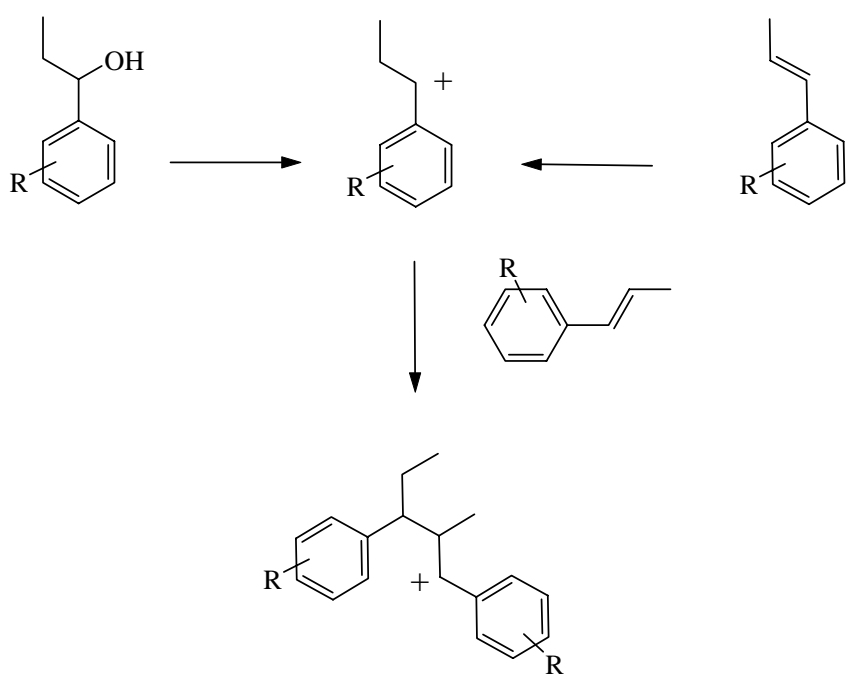

\section{Scheme 1}


The dimerisation of asarone using hydrogen chloride or trifluoroacetic acid leads to the $\gamma$ configured cyclodimer. ${ }^{14}$

In this work, different pathways are described to obtain the natural asarone cyclodimer $\mathbf{2}$ and it is studied how the substitution pattern, in the aromatic rings of precursors, determines the steric course of cyclodimerisation.

\section{Results and Discussion}

The asarone dimer was obtained by three different routes and the product compared with the natural dimer extracted from Accorus calamus (Scheme 2).

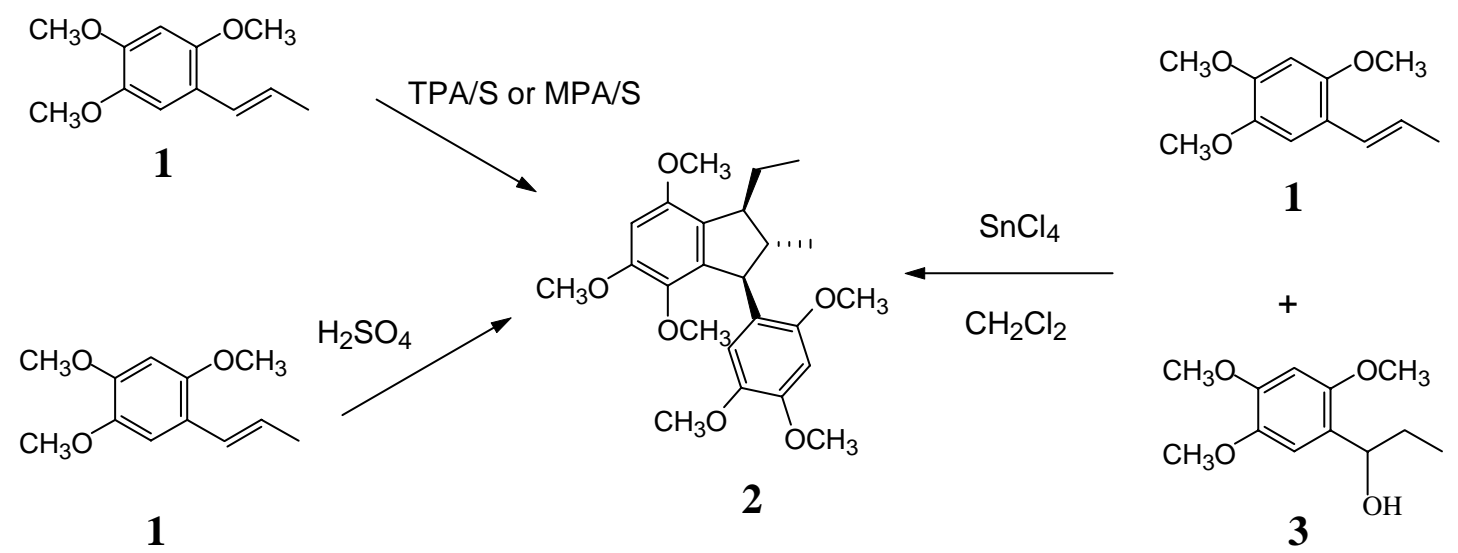

\section{Scheme 2}

All routes led to the $\gamma$ stereoisomer as a racemic mixture and as the principal product. Its physical data coincided with those of the natural product, $r$-1-ethyl-t-2-methyl-c-3-(2,4,5trimethoxyphenyl)-4,5,7-trimethoxyindane; however, the yield of the reactions was variable.

The dimerisation of asarone catalysed by sulphuric acid $50 \%\left(30 \mathrm{~min} ., 70^{\circ} \mathrm{C}\right)$ afforded 2, with $13 \%$ yield. The synthesis of the indane structure via formal [3+2] cycloaddition ${ }^{11}$ from asarone and its derivative alcohol 3, catalysed by $\mathrm{SnCl}_{4}\left(30 \mathrm{~min} ., 0^{\circ} \mathrm{C}\right)$ afforded 2, with $40 \%$ yield. The highest yield (62\%) was obtained when asarone dimerisation was carried out with TPA/S and MPA/S, using chloroform as solvent (1h, reflux temperature). In this synthetic process a secondary product 4, 1-(2,4,5-trimethoxyphenyl)propane, ${ }^{15}$ was detected, whose formation may be explained by the "ionic hydrogenation" method. ${ }^{16}$ 


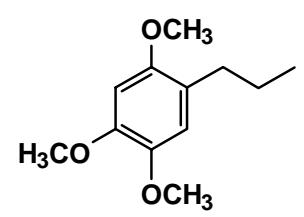

4

Figure 2

An obvious question that arises is why asarone dimerisation, using diverse acid catalysts or formal [3+2] cycloaddition, leads to the $\gamma$ configured indane, when these reactions generally result in the $\alpha$ indane configuration. Quite likely, one of the causes of the end product stereochemistry is the aryl substitution pattern of the starting products. In order to confirm such influence, a series of indanes differently substituted in the aromatic rings was synthesised.

In a previous paper, we reported the dimerisation of isosafrole 5 using TPA/S or MPA/S as catalysts. ${ }^{10}$ In both cases the racemates $\alpha(7)$ and $\gamma(\mathbf{8})$ were obtained in a 3:1 ratio. When the reaction was carried out via formal [3+2] cycloaddition, using 5 and 1-(3,4methylenedioxyphenyl)propanol 6, compounds 7 ( $\alpha$-racemate) and $\mathbf{8}$ ( $\gamma$-racemate) were obtained in a 7:1 ratio (Scheme 3).

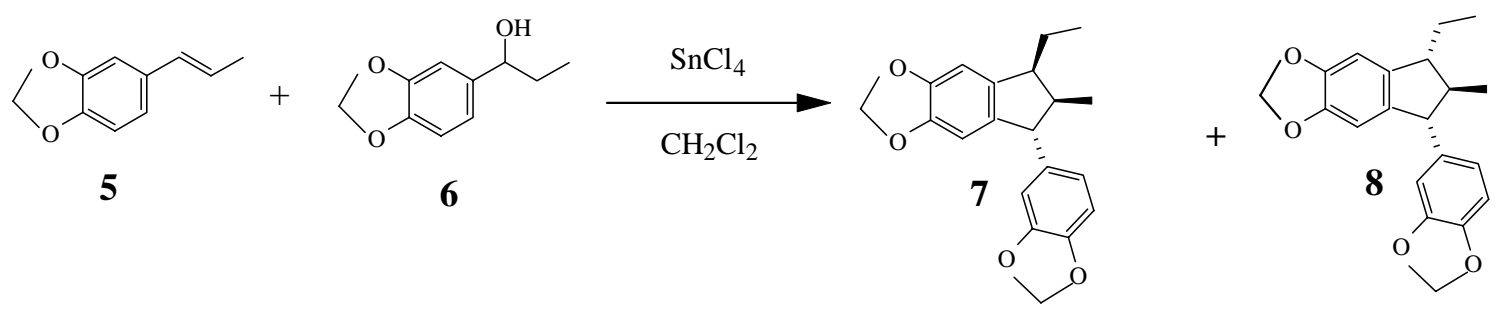

\section{Scheme 3}

The prevalence of $\alpha$ stereochemistry was also observed when 3,4,5-trimethoxystyrene 9 was treated with TPA/S affording dimeric compound 10 (Scheme 4); In the ${ }^{13} \mathrm{C}-\mathrm{NMR}$ spectra of crude reaction it is observed the presence of signals of aliphatic carbons which are coincident which those described for $\gamma$ isomers. ${ }^{4,10}$ When $\mathbf{9}$ was treated with alcohol $\mathbf{1 1}$ in the presence of $\mathrm{SnCl}_{4}$ the same dimer $\mathbf{1 0}$ was obtained. In the crude reaction mixture the presence of another diastereomer was not detected. 


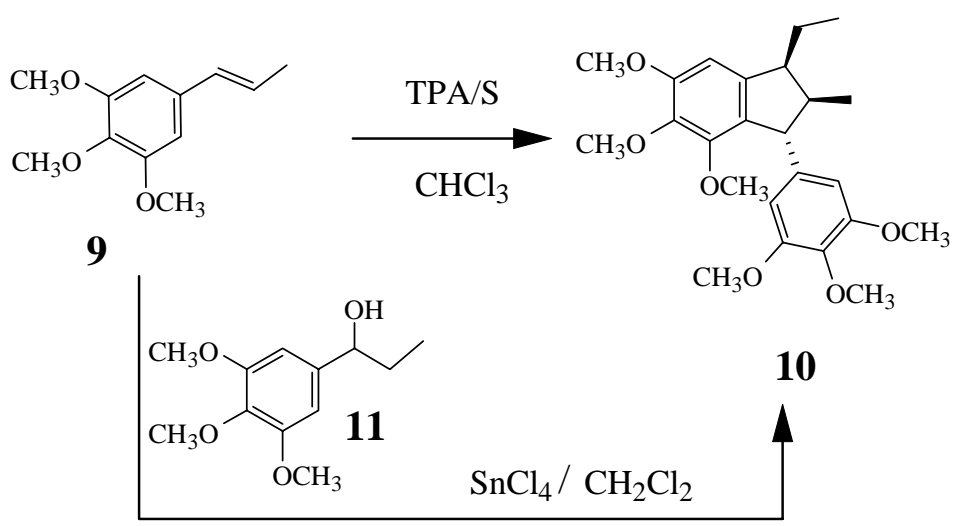

\section{Scheme 4}

Differently substituted dimers were obtained from asarone $\mathbf{1}$ and several alcohols, namely, $\mathbf{6}$, 11 and 13, using formal [3+2] cycloaddition (Scheme 5). The main compounds obtained were 12, 15, and 14 respectively, all with $\alpha$ configuration. However, when alcohol 3 was treated with 1-methoxy-4-[(1E)-1-propenyl]-benzene 16, indane 17 with $\gamma$ configuration was obtained as the only product.
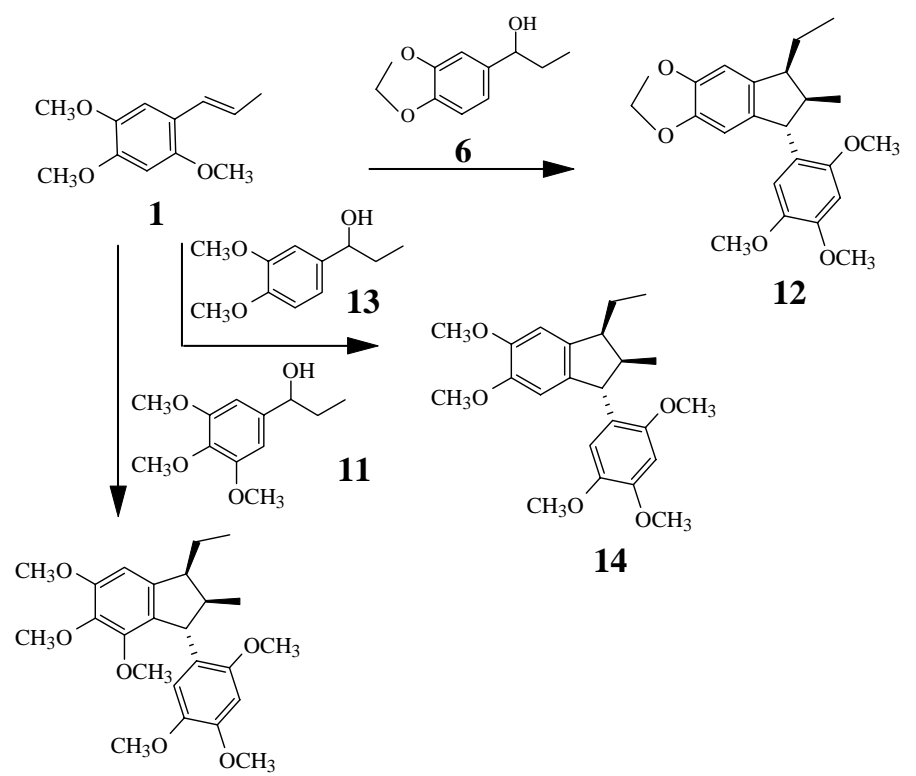

14

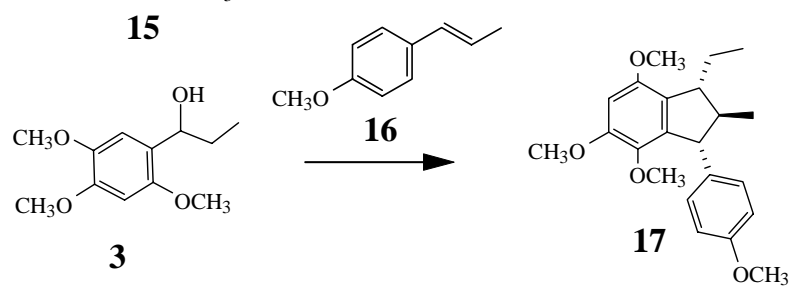

\section{Scheme 5}


When 16 was treated with alcohols 11 and 13, it rendered indanes 18 and 19, both with $\alpha$ configuration (Scheme 6).

From these results it was inferred that, in order to obtain the $\gamma$ isomer, at least two methoxy groups are required in 2 and 5-positions in the starting alkene in cyclodimerisation reactions, or in the alcohol in the case of formal [3+2] cycloaddition.

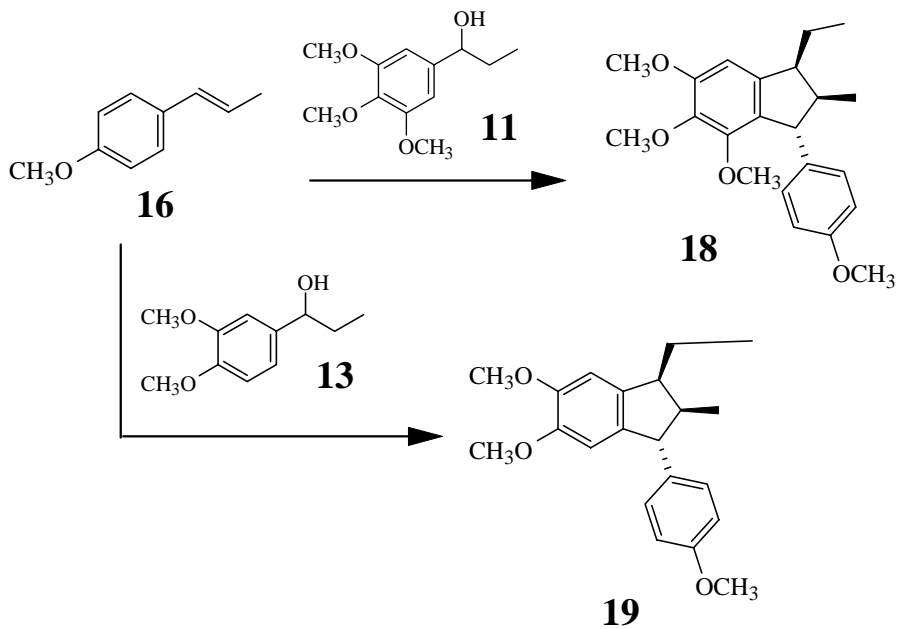

\section{Scheme 6}

\section{Determination of indane configuration by NMR spectroscopy}

To confirm structures and stereochemistry of synthesised indanes, chemical shifts of hydrogen and carbon atoms were unequivocally assigned by 2D-NMR experiments.

Comparison of ${ }^{1} \mathrm{H}$-NMR spectra of indanes of assigned $\gamma$ configuration $(\gamma$-diasarone 2 , indane 17, $\gamma$-diisohomogenol and $\gamma$-diisosafrole) disclosed remarkable coincidences (Table 1), except for $\mathrm{H}-3$ of 2 which is highly deshielded $(4.27 \mathrm{ppm})$ and its chemical shift is similar to those of $\mathrm{H}$-3 in $\beta$-diisohomogenol (4.27 ppm) and $\beta$-metanethole (4.28 ppm). ${ }^{8}$

Table 1. Chemical shifts in ${ }^{1} \mathrm{H}-\mathrm{NMR}$ spectra of aliphatic hydrogen atoms in $\gamma$ indanes

\begin{tabular}{lllllll}
\hline Dimers/ $\delta(\mathrm{ppm})$ & $\mathrm{H}-1$ & $\mathrm{H}-2$ & $\mathrm{H}-3$ & $\mathrm{CH}_{3}$ & $\mathrm{CH}_{2} \mathrm{CH}_{3}$ & $\mathrm{CH}_{2} \underline{\mathrm{CH}_{3}}$ \\
\hline$\gamma$-diasarone (2) & 2.67 & 2.07 & 4.27 & 1.17 & 1.451 .83 & 0.85 \\
$\gamma$-indane (17) & 2.75 & 2.12 & 3.88 & 1.19 & 1.631 .94 & 0.91 \\
$\gamma$-diisohomogenol & 2.69 & 2.00 & 3.65 & 1.15 & 1.80 & 1.00 \\
$\gamma$-diisosafrole & 2.65 & 1.96 & 3.52 & 1.10 & 1.75 & 0.97 \\
\hline
\end{tabular}

Table 2 summarises ${ }^{1} \mathrm{H}-\mathrm{NMR}$ data of aliphatic hydrogen atoms of indanes of assigned $\alpha$ configuration.

Chemical shifts of aliphatic hydrogen atoms in indanes 10, 12, 14, 15, 18 and 19 are very 
similar exception made for H-3 in compounds 12, 14 and 15 that were markedly deshielded, probably due to the methoxyl group in ortho position of the aryl ring at C-3.

Table 2. Chemical shifts in ${ }^{1} \mathrm{H}-\mathrm{NMR}$ spectra of aliphatic hydrogen atoms in $\alpha$ indanes

\begin{tabular}{lcccccc}
\hline $\begin{array}{l}\text { Dimers/ } \\
\delta(\mathrm{ppm})\end{array}$ & $\mathrm{H}-1$ & $\mathrm{H}-2$ & $\mathrm{H}-3$ & $\mathrm{CH}_{3}$ & $\underline{\mathrm{CH}_{2} \mathrm{CH}_{3}}$ & $\mathrm{CH}_{2} \underline{\mathrm{CH}}_{3}$ \\
\hline 10 & 3.00 & 2.46 & 3.90 & 1.01 & 1.58 & 0.95 \\
12 & 2.90 & 2.51 & 4.31 & 1.03 & $1.49 / 1.69$ & 0.99 \\
14 & 2.91 & 2.43 & 4.33 & 1.02 & $1.55 / 1.75$ & 0.96 \\
15 & 2.93 & 2.36 & 4.33 & 0.97 & $1.54 / 1.73$ & 0.95 \\
18 & 3.04 & 2.47 & 3.95 & 1.02 & 1.62 & 0.98 \\
19 & 2.95 & 2.47 & 3.84 & 1.06 & $1.42 / 1.73$ & 1.00 \\
\hline
\end{tabular}

Inter-proton coupling constants of hydrogen atoms in the five-member ring of several indanes of $\alpha, \beta$ and $\gamma$ configuration are listed in Table 3. A quick inspection of Figure 1 shows that $\beta$-and $\gamma$-isomers have protons $\mathrm{H}-1$ and $\mathrm{H}-3$ in the same arrangement, cis and trans respectively, relative to $\mathrm{H}-2$. This should lead to a high similarity in the observed $\mathrm{J}_{1,2}$ and $\mathrm{J}_{2,3}$ couplings for the compounds in $\beta$ - and $\gamma$-configurations. In contrast, the $\alpha$-isomers, with $\mathrm{H}-1$ and $\mathrm{H}-3$ in opposite arrangement with respect to $\mathrm{H}-2$, should display dissimilar $\mathrm{J}_{1,2}$ and $\mathrm{J}_{2,3}$ couplings. These facts are punctually observed in Table 3. A detailed conformational analysis is performed below to explain the particular couplings displayed by 14 and 15, within $\alpha$-isomers, and 2 and 17 within $\gamma$-ones

Table 3. Coupling constants of aliphatic hydrogen atoms in $\alpha, \beta$ and $\gamma$ indanes

\begin{tabular}{lll}
\hline Dimers/ J (Hz) & $\mathrm{J}_{1,2}$ & $\mathrm{~J}_{2,3}$ \\
\hline$\alpha$-diisohomogenol & 7.2 & 9.5 \\
$\alpha$-diisosafrole & 7.1 & 9.4 \\
$12(\alpha)$ & 6.8 & 8.4 \\
$14(\alpha)$ & 6.9 & 7.9 \\
$15(\alpha)$ & 7.2 & 3.6 \\
$18(\alpha)$ & 7.1 & 5.1 \\
$19(\alpha)$ & 7.1 & 9.1 \\
$\beta$-diisohomogenol & 7.0 & 7.0 \\
$\beta$-metanethole & 7.0 & 7.0 \\
$\gamma$-diisosafrole & 9.5 & 9.0 \\
$\gamma$-diasarone $(2)$ & 4.2 & 4.3 \\
$17(\gamma)$ & 5.5 & 5.3 \\
\hline
\end{tabular}


The chemical shifts of ${ }^{13} \mathrm{C}-\mathrm{NMR}$ spectra of the $\alpha, \beta$ and $\gamma$ diatereomeric indanes are summarised in Table 4.

The comparison of the shifts of aliphatic carbon atoms in $\alpha$-diisohomogenol, $\alpha$-diisosafrole (7) and $\alpha$ diastereomers 10,12, 14, 15, 18 and 19, revealed marked coincidences in the aliphatic carbons except for $\mathrm{C}-3$ in the case of indanes 12, 14 and 15. The latter three indanes are significant for presenting the aryl group bound to C-3, with the same substitution pattern found in asarone.

In the case of $\gamma$ configured indanes 2 and 17, their similarity is also noteworthy, though the deshielding presented by the methyl group bound to $\mathrm{C}-2$ and by the ethyl group methylene bound to $\mathrm{C}-1$, with regard to the other diastereomers, should be highlighted. These values concur with an all trans arrangement of the substituents because the shielding rgauche trans effect, is smaller than the cis. Due to this rgauche trans effect, a greater deshielding is observed when the methyl group is in the trans arrangement with the substituent on C-1 and C-3. All these observations agree with the $\gamma$ configuration, which was originally assigned to the natural indane 2, and confirm the stereochemistry of compound $\mathbf{1 7}$ as well, making the ${ }^{13} \mathrm{C}-\mathrm{NMR}$ spectrum a useful tool for the configuration assignment of these compounds.

Table 4. ${ }^{13} \mathrm{C}-\mathrm{NMR}$ : chemical shifts of aliphatic carbon atoms in several indanes

\begin{tabular}{lllllll}
\hline Dimers/ $\delta(\mathrm{ppm})$ & $\mathrm{C}-1$ & $\mathrm{C}-2$ & $\mathrm{C}-3$ & $\mathrm{CH}_{3}$ & $\mathrm{CH}_{2} \mathrm{CH}_{3}$ & $\mathrm{CH}_{2} \mathrm{CH}_{3}$ \\
\hline$\alpha$-diisohomogenol & 48.3 & 49.3 & 56.7 & 13.6 & 22.2 & 12.0 \\
$\alpha$-diisosafrole & 48.3 & 49.4 & 56.7 & 13.7 & 22.0 & 12.1 \\
$7(\alpha)$ & 48.3 & 49.4 & 56.7 & 13.6 & 22.2 & 12.0 \\
$10(\alpha)$ & 48.3 & 48.9 & 56.6 & 15.4 & 22.5 & 12.9 \\
$12(\alpha)$ & 48.7 & 48.8 & 49.0 & 14.6 & 22.6 & 12.8 \\
$14(\alpha)$ & 48.9 & 49.0 & 49.5 & 14.7 & 22.7 & 12.9 \\
$15(\alpha)$ & 48.5 & 48.2 & 46.6 & 15.3 & 22.0 & 12.9 \\
$18(\alpha)$ & 48.7 & 48.4 & 55.4 & 15.2 & 22.5 & 12.9 \\
\hline
\end{tabular}

\section{Conformational analysis}

The considerable difference in coupling constants of the $\gamma$ dimer of asarone $\mathbf{2}$ and $\mathbf{1 7}$ and the deshielding of $\mathrm{H}-3$, in relation to other styrene dimers with $\gamma$ configuration, may be explained by taking into account extreme conformations for each indane. Using computational calculation tools and employing the semi-empirical method AM1, ${ }^{17}$ conformational analysis indicated that the most stable conformer for compounds $\mathbf{2}$ and $\mathbf{1 7}$ is that possessing the substituents in an all pseudoaxial arrangement, i.e., conformation $\gamma$-b, where $\mathrm{H}-1$ and $\mathrm{H}-3$ are in a gauche arrangement relative to $\mathrm{H}-2$ and should display similar small $\mathrm{J}_{1,2}$ and $\mathrm{J}_{2,3}$ couplings, in accordance with our observations (cf. Table 3). 


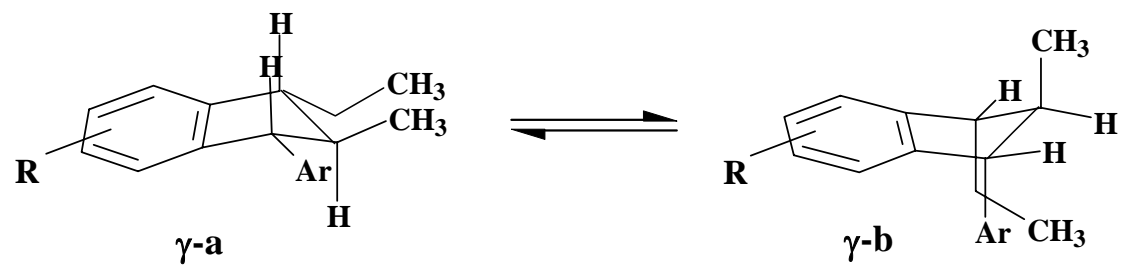

\section{Figure 3}

Calculations predict for $\mathbf{2}$ and $\mathbf{1 7}$ that the 1,3 interaction in the $\boldsymbol{\gamma}$-b conformer between pseudoaxial substituents on C-1 and C-3 is lower than that in conformation $\gamma$-a, between such substituents in peudoequatorial position and the methoxyl groups placed on C-4 and C-7 of the indane (Fig 4). This is due to the presence of the substituent at the ortho position of the aromatic ring at $\mathrm{C}-3$.

The rest of dimers in $\gamma$ configuration, lacking the aforementioned substituent, are predicted to prefer the all-pseudoequatorial conformation $\gamma$-a, where $\mathrm{H}-1$ and $\mathrm{H}-3$ are in an anti arrangement relative to $\mathrm{H}-2$ and should display also similar but high $\mathrm{J}_{1,2}$ and $\mathbf{J}_{2,3}$ couplings, in agreement with the experimental values (Table 3).
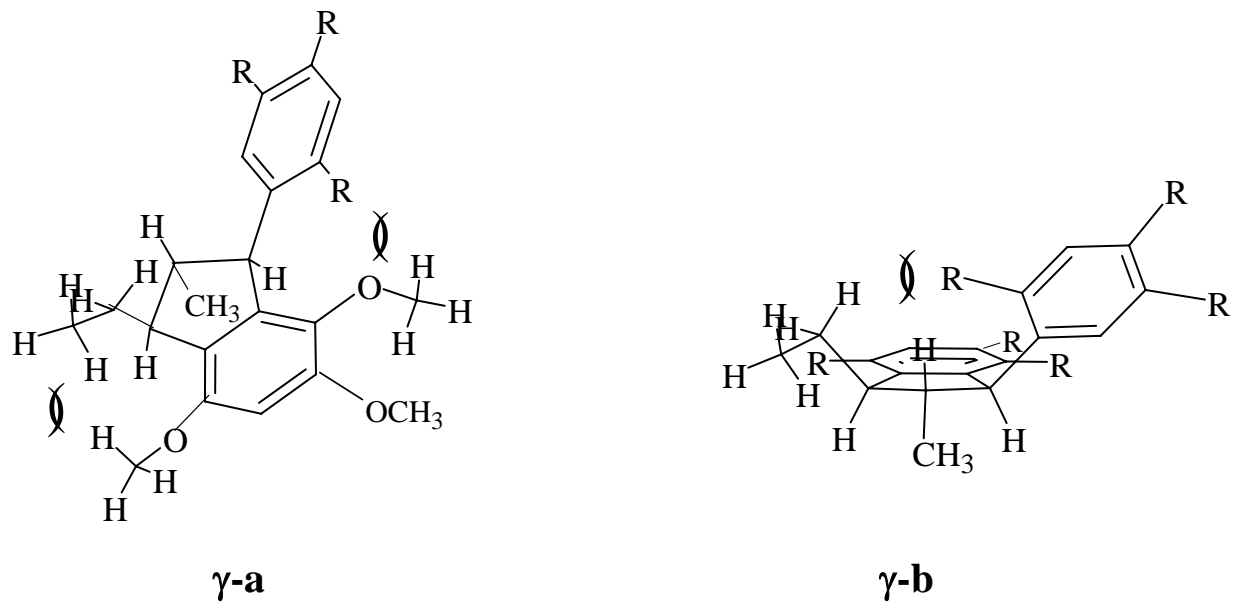

\section{Figure 4}

Dimers 12 and 19, of $\alpha$ configuration, are predicted to be in $\alpha$-a as the preferred conformation (Figure 5). The expectation of $\mathrm{J}_{2,3}$ (anti) being higher that $\mathrm{J}_{1,2}$ (gauche) is observed in Table 3. Isosafrole and isohomogenol dimers with the same configuration behave likewise. Instead, $\mathrm{J}_{1,2}>\mathrm{J}_{2,3}$ in indanes 10, 15 and 18 suggest a preference for the $\boldsymbol{\alpha}$-b conformation, probably due to the presence of the methoxyl group bound to the C-4 of the indane skeleton (Fig. 5). Finally, the similar coupling constants of compound $\mathbf{1 4}$ suggest there is no conformational preference in this case. 


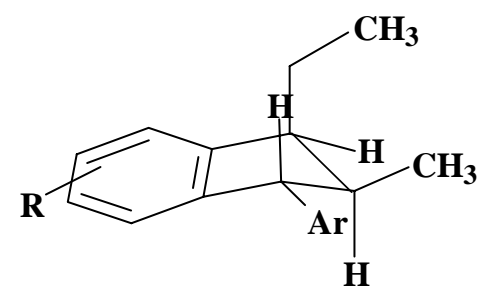

$\alpha-\mathbf{a}$

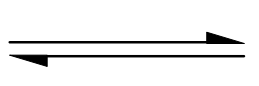

Figure 5

\section{Origin of stereocontrol}

While in isosafrole and isohomogenol dimerisations catalysed by sulphuric acid, ${ }^{8} \mathrm{EPP}^{9}$ or heteropolyacids, ${ }^{10}$ the compound mainly obtained is the one with the $\alpha$ configuration, in the case of asarone and indane $\mathbf{1 7}$ the only dimeric product afforded is the $\gamma$ compound. This divergence could be interpreted by studying the possible structures of transition states by AM1 calculations. For isosafrole and isohomogenol, a type Ia approach (Figure 6) offers the advantage of minimising non-bonding interactions and allowing a certain degree of $\pi$ stacking interaction between aromatic rings. This approach could lead to the Ib intermediate, which via intramolecular cyclisation would afford the $\alpha$-configured isomer.

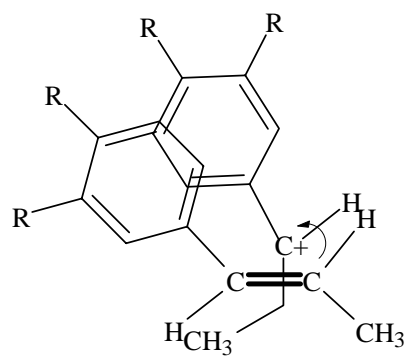

Ia

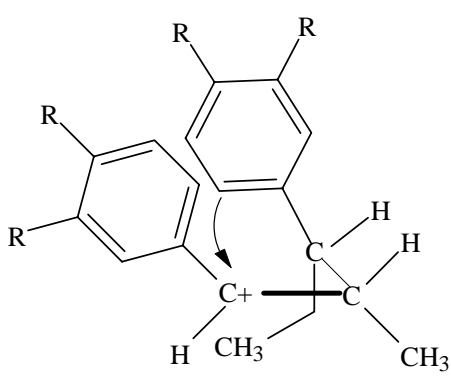

Ib

\section{Figure 6}

In the dimerisation of asarone and in the synthesis of 17, the presence of methoxyl groups in both ortho positions in the aromatic indane ring could destabilise Ia on steric grounds, thus making the type IIa approach (Figure 7) the most probable one, which in turn would generate intermediate IIb. Subsequent carbon-carbon bond rotation and cyclisation (IIc), would lead the pentagonal ring with the observed all trans substitution pattern. 


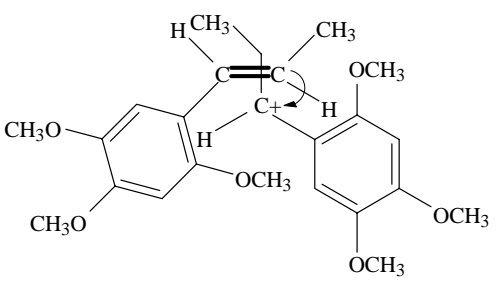

IIa

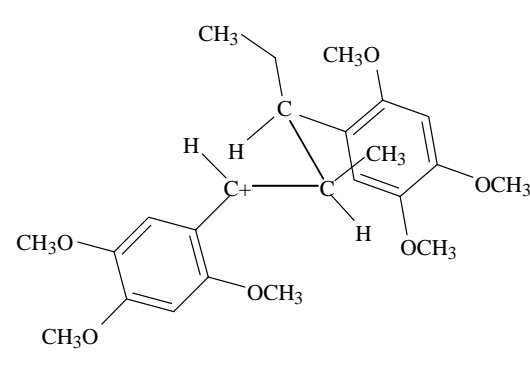

IIb

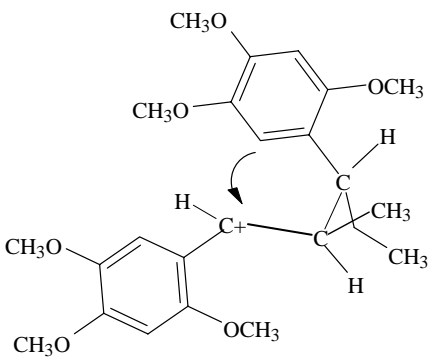

IIc

Figure 7

\section{Experimental Section}

General Procedures. The ${ }^{1} \mathrm{H}$ - and ${ }^{13} \mathrm{C}-\mathrm{NMR}$ spectra were recorded with a Bruker AC-300 spectrometer with $\mathrm{CDCl}_{3}$ as solvent, employing $\mathrm{Me}_{4} \mathrm{Si}$ as internal standard ( $\left.\delta: 0.00\right), J$ values are given in Hz. 2D-NMR experiments were recorded on a Bruker AC-500 instrument by using standard Bruker software. Melting point (uncorrected) was obtained with a Thomas Hoover apparatus. Preparative thin layer chromatography (p-tlc) was performed on a 20x20 cm glass plate coated with silica gel $60 \mathrm{~F}_{254}(0.50 \mathrm{~mm})$. Elemental analyses were carried out in our laboratories with a Coleman Analyser.

Cyclodimerisation of asarone with TPA/S or MPA/S. A mixture of asarone (0.104 g, 0.5 $\mathrm{mmol}$ ) in chloroform (3 mL) and catalyst (0.05 meq; TPA/S: $100 \mathrm{mg}, \mathrm{MPA} / \mathrm{S}: 50 \mathrm{mg})$ was heated at reflux during $1 \mathrm{~h}$. After completion of reaction, monitoring by tlc, the catalyst was removed by filtration and the solvent evaporated under reduced pressure. The residue was purified via p-tlc using chloroform as solvent of elution yielding 2 (50\%) as a solid; mp: 84-5 ${ }^{\circ} \mathrm{C}$, lit ${ }^{4}: 84^{\circ} \mathrm{C}$.

Cyclodimerisation of asarone with sulphuric acid. A mixture of asarone (100 $\mathrm{mg}, 0.476$ $\mathrm{mmol})$ in water $(30 \mathrm{~mL})$ and concd. sulphuric acid $(30 \mathrm{~mL})$ was stirred for 30 minutes at $70{ }^{\circ} \mathrm{C}$ : Then water (30 mL) was added and the crude product was extracted with chloroform (3x20mL). The organic layer was washed with aqueous solution of $\mathrm{NaOH}$ (5\%) and water, dried over anhydrous $\mathrm{Na}_{2} \mathrm{SO}_{4}$ and the solvent was evaporated in vacuo. The compound 2 was purified by ptlc using chloroform as solvent of elution; mp: $84-5{ }^{\circ} \mathrm{C}$, lit ${ }^{4}: 84^{\circ} \mathrm{C}$. Yield: $13 \%$.

Dimer of asarone by a formal cycloaddition [3+2] reaction. To a solution of 1-(2,4,5trimethoxyphenyl)ethanol $3(0.104 \mathrm{~g}, 0.464 \mathrm{mmol})$ and asarone $(0.125 \mathrm{~g}, 0.742 \mathrm{mmol})$ in dry $\mathrm{Cl}_{2} \mathrm{CH}_{2}(10 \mathrm{~mL})$ at $0^{\circ} \mathrm{C}$, was added, with stirring, $\mathrm{SnCl}_{4}(0.07 \mathrm{~mL}, 0.60 \mathrm{mmol})$. After 30 minutes the temperature was raised at room temperature and a $\mathrm{NaCO}_{3} \mathrm{H} 5 \%$ solution $(10 \mathrm{~mL})$ was incorporated. The organic layer was separated, washed with water, dried over anhydrous $\mathrm{Na}_{2} \mathrm{SO}_{4}$ and the solvent was evaporated in vacuo. Purification of the residue by p-tlc using chloroform as 
solvent of elution afforded product 2; mp: $84-5{ }^{\circ} \mathrm{C}$, lit ${ }^{4}: 84^{\circ} \mathrm{C}$. Yield $40 \%$.

1-(2,4,5-Trimethoxyphenyl)propan-1-ol (3). ${ }^{18}$ Ethyl magnesium bromide (7.0 mmol in THF 5 $\mathrm{mL}$ ) was added dropwise to a stirred solution of 2,4,5-trimethoxybenzaldehyde (5 mL, 3.28 mmol) at room temperature. The solution was stirred for $2 \mathrm{~h}$. Aqueous work up $\left(\mathrm{H}_{2} \mathrm{O}, \mathrm{NH}_{4} \mathrm{OH}\right.$, ether) afforded 3 as white solid, mp: 68-70 $\mathrm{C}^{\circ}(0.510 \mathrm{~g}, 71 \%)$.

NMR data: $\delta_{\mathrm{H}}: 0.93\left(3 \mathrm{H}, \mathrm{t}, \mathrm{J}: 7.0 \mathrm{~Hz}, \mathrm{CH}_{3}\right), 1.76\left(2 \mathrm{H}, \mathrm{m}, \mathrm{CH}_{2}\right), 2.39(1 \mathrm{H}, \mathrm{s}, \mathrm{OH}), 3.81(3 \mathrm{H}, \mathrm{s}$, $\left.\mathrm{OCH}_{3}\right), 3.83\left(3 \mathrm{H}, \mathrm{s}, \mathrm{OCH}_{3}\right), 3.87\left(3 \mathrm{H}, \mathrm{s}, \mathrm{OCH}_{3}\right), 4.77(1 \mathrm{H}, \mathrm{dd}, J: 5.1$ and $8.9 \mathrm{~Hz}, \mathrm{CH}), 6.51(1 \mathrm{H}$, s, Ar), $6.87(1 \mathrm{H}, \mathrm{s}, \mathrm{Ar}) . \delta_{\mathrm{C}} 10.4,30.4,56.2$ (2), 56.6, 71.5, 97.6, 111.1, 124.2, 143.1, 148.6, 150.7 .

1-(3,4-Metlylenedioxyphenyl)propan-1-ol (6). ${ }^{19}$ The same procedure described for the preparation of 3 was carried out with ethylmagnesium bromide (28 mmol in $14 \mathrm{~mL}$ of THF) and piperonal (13.1 mmol in $2 \mathrm{~mL}$ of THF) afforded 6 as clear oil (1.6 g , 68 \%).

NMR data: $\delta_{\mathrm{H}}: 0.90\left(3 \mathrm{H}, \mathrm{t}, J: 7.4 \mathrm{~Hz}, \mathrm{CH}_{3}\right), 1.70\left(1 \mathrm{H}, \mathrm{m}, \mathrm{J}:\right.$ 6.3, 7.4 and $\left.14.7 \mathrm{~Hz}, \mathrm{CH}_{2}\right), 1.79$ (1H, m, J: 6.3, 7.4 and $\left.14.7 \mathrm{~Hz}, \mathrm{CH}_{2}\right), 1.89$ (1H, s, OH), 4.51 (1H, t, J: $\left.6.5 \mathrm{~Hz}, \mathrm{CH}\right), 5.95$ (2H, s, $\left.\mathrm{OCH}_{2} \mathrm{O}\right), 6.78\left(2 \mathrm{H}\right.$, br s, Ar), $6.87(1 \mathrm{H}, \mathrm{s}, \mathrm{Ar}) . \delta_{\mathrm{C}} 10.5,32.2,76.3,101.3,106.8,108.4,119.8$, 139.1, 147.2, 148.1.

1-(3,4,5-Trimethoxyphenyl)propan-1-ol (11). ${ }^{20}$ The same procedure described for the preparation of 3 was carried out with ethylmagnesium bromide (14 mmol in $7 \mathrm{~mL}$ of THF) and 3,4,5trimethoxybenzaldehyde (6.53 mmol in $2 \mathrm{~mL}$ of THF) afforded 11 as clear oil (1.12 g , 39 \%).

NMR data: $\delta_{\mathrm{H}}: 0.94\left(3 \mathrm{H}, \mathrm{t}, \mathrm{J}: 6.0 \mathrm{~Hz}, \mathrm{CH}_{3}\right), 1.77\left(2 \mathrm{H}, \mathrm{m}, \mathrm{CH}_{2}\right), 2.09(1 \mathrm{H}, \mathrm{s}, \mathrm{OH}), 3.83(3 \mathrm{H}, \mathrm{s}$, $\left.\mathrm{OCH}_{3}\right), 3.86\left(6 \mathrm{H}, \mathrm{s}, \mathrm{OCH}_{3}\right), 4.52(1 \mathrm{H}, \mathrm{t}, \mathrm{J}: 6.0 \mathrm{~Hz}, \mathrm{CH}), 6.57$ (2H, s, Ar). $\delta_{\mathrm{C}} 10.6,32.3$, 56.2 (2), 61.2, 76.6, 103.2 (2), 137.5, 140.9, $153.6(2)$.

1-(3,4-Dimethoxyphenyl)propan-1-ol (13). ${ }^{21}$ The same procedure described for the preparation of 3 was carried out with ethylmagnesium bromide $(28 \mathrm{mmol}$ in THF $(14 \mathrm{~mL})$ and 3,4dimethoxybenzaldehyde (13.1 mmol in $2 \mathrm{~mL}$ of THF) afforded 13 as clear oil (2.0 g, 78 \%).

NMR data: $\delta_{\mathrm{H}}: 0.88\left(3 \mathrm{H}, \mathrm{t}, \mathrm{J}: 6.3 \mathrm{~Hz}, \mathrm{CH}_{3}\right), 1.69\left(1 \mathrm{H}, \mathrm{m}, \mathrm{J}: 6.3,7.5\right.$ and $\left.13.8 \mathrm{~Hz}, \mathrm{CH}_{2}\right), 1.79$ $\left(1 \mathrm{H}, \mathrm{m}, \mathrm{J}\right.$ : 6.3, 7.3 and $\left.13.8 \mathrm{~Hz}, \mathrm{CH}_{2}\right), 2.26(1 \mathrm{H}, \mathrm{s}, \mathrm{OH}), 3.84\left(3 \mathrm{H}, \mathrm{s}, \mathrm{OCH}_{3}\right), 3.86\left(3 \mathrm{H}, \mathrm{s}, \mathrm{OCH}_{3}\right)$, 4.49 (1H, t, J: $6.6 \mathrm{~Hz}, \mathrm{CH}), 6.81(1 \mathrm{H}, \mathrm{d}, J: 8.1 \mathrm{~Hz}, \mathrm{Ar}), 6.83(1 \mathrm{H}, \mathrm{dd}, J: 1.6$ and $8.1 \mathrm{~Hz}, \mathrm{Ar}), 6.88$ $(1 \mathrm{H}, \mathrm{d}, \mathrm{J}: 1.5 \mathrm{~Hz}, \mathrm{Ar}) . \delta_{\mathrm{C}} 10.6,32.2$, 56.2, 56.3, 76.2, 109.4, 113.3, 118.6, 137.7, 148.7, 149.3.

r-1-Ethyl-c-2-methyl-t-3-(3,4-methylenedioxyphenyl)-5,6-methylenedioxyindane (7). General procedure was carried out using alcohol 6 (0.100 g, $0.55 \mathrm{mmol})$, styrene 5 (0.0891 g, $0.55 \mathrm{mmol})$ and $\mathrm{SnCl}_{4}$ (0.185 g, $0.71 \mathrm{mmol})$ afforded a mixture of 7 and 80 (7:1) as an oil (140 g, 78\%). The NMR spectra were coincident with those informed in lit. ${ }^{10}$

r-1-Ethyl-c-2-methyl-t-3-(3,4,5-trimethoxyphenyl)-4,5,6-trimethoxyindane (10). General procedure was carried out using alcohol 11 (0.0246 g, $0.1086 \mathrm{mmol})$, styrene 9 (0.0226 g, $0.1086 \mathrm{mmol}$ ) and $\mathrm{SnCl}_{4}(0.036 \mathrm{~g}, 0.14 \mathrm{mmol})$ afforded 10 as clear oil $(0.0276 \mathrm{~g}, 61 \%)$. This compound was obtained by cyclodimerization of styrene 9 (130 mg, $0.57 \mathrm{mmol})$ with MPA/S (58 $\mathrm{mg})$ using the procedure indicated above. Yield $78 \mathrm{mg}(66 \%)$.

NMR data: $\delta_{\mathrm{H}}: 0.95\left(3 \mathrm{H}, \mathrm{t}, \mathrm{J}: 7.4 \mathrm{~Hz}, \mathrm{CH}_{2} \mathrm{CH}_{3}\right), 1.01\left(3 \mathrm{H}, \mathrm{d}, \mathrm{J}: 6.9 \mathrm{~Hz}, \mathrm{CHCH}_{3}\right), 1.58$ (2H, m, $\left.\mathrm{CH}_{2} \mathrm{CH}_{3}\right), 2.46\left(1 \mathrm{H}, \mathrm{m}, \mathrm{CHCH}_{3}\right), 3.00\left(1 \mathrm{H}, \mathrm{m}, \mathrm{CHCH}_{2}\right), 3.49\left(3 \mathrm{H}, \mathrm{s}, \mathrm{OCH}_{3}\right), 3.76(6 \mathrm{H}, \mathrm{s}$, 
$\left.\mathrm{OCH}_{3}\right), 3.80\left(3 \mathrm{H}, \mathrm{s}, \mathrm{OCH}_{3}\right), 3.81\left(3 \mathrm{H}, \mathrm{s}, \mathrm{OCH}_{3}\right), 3.87\left(3 \mathrm{H}, \mathrm{s}, \mathrm{OCH}_{3}\right), 3.90(1 \mathrm{H}, \mathrm{d}, \mathrm{J}: 5,1 \mathrm{~Hz}$, CHPh), 6.28 (2H, s, Ar), $6.56(1 \mathrm{H}, \mathrm{s}, \mathrm{Ar}) . \delta_{\mathrm{C}}: 12.9,15.4,22.5,48.3,48.9,56.6,56.7,56.8,60.9$, 61.5, 104.0, 105.3, 130.1, 136.8, 141.4, 143.6, 151.0, 153.5, 153.8. Calcd. for $\mathrm{C}_{24} \mathrm{H}_{32} \mathrm{O}_{6} \mathrm{C} 69.21$, H 7.74; found C 69.02, H 7.80.

r-1-Ethyl-c-2-methyl-t-3-(2,4,5-trimethoxyphenyl)-5,6-methylenedioxyindane (12). General procedure was carried out using alcohol 6 (0.090 g, $0.5 \mathrm{mmol})$, styrene 1 (0.104 g, $0.5 \mathrm{mmol})$ and $\mathrm{SnCl}_{4}(0.169 \mathrm{~g}, 0.65 \mathrm{mmol})$ afforded by p-tlc (hexane: ethyl acetate, 80:20) 12 as clear oil (0.0839 g, 46\%).

NMR data: $\delta_{\mathrm{H}}: 0.99\left(3 \mathrm{H}, \mathrm{t}, J: 7.3 \mathrm{~Hz}, \mathrm{CH}_{2} \mathrm{CH}_{3}\right), 1.03\left(3 \mathrm{H}, \mathrm{d}, J: 7.1 \mathrm{~Hz}, \mathrm{CHCH}_{3}\right), 1.49$ (1H, m, $J$ : 7.3, 7.3 and $\left.14.9 \mathrm{~Hz}, \mathrm{CH}_{2} \mathrm{CH}_{3}\right), 1.69\left(1 \mathrm{H}, \mathrm{m}, \mathrm{CH}_{2} \mathrm{CH}_{3}\right), 2.51(1 \mathrm{H}, \mathrm{m}, J:$ 6.8, 7.1 and $8.3 \mathrm{~Hz}$, $\left.\mathrm{CHCH}_{3}\right), 2.90\left(1 \mathrm{H}, \mathrm{m}, \mathrm{CHCH}_{2}\right), 3.72\left(3 \mathrm{H}, \mathrm{s}, \mathrm{OCH}_{3}\right), 3.85\left(3 \mathrm{H}, \mathrm{s}, \mathrm{OCH}_{3}\right), 3.92\left(3 \mathrm{H}, \mathrm{s}, \mathrm{OCH}_{3}\right)$, 4.31 (1H, d, J: 8.4 Hz, CHAr), 5.90 (1H, d, J: 1.5 Hz, O-CH $-\mathrm{O}), 5.92$ (1H, d, J: 1.5 Hz, O-CHzO), $6.39(1 \mathrm{H}, \mathrm{s}, \mathrm{Ar}), 6.46(1 \mathrm{H}, \mathrm{s}, \mathrm{Ar}), 6.60(1 \mathrm{H}, \mathrm{s}, \mathrm{Ar}), 6.75$ (1H, s, Ar). $\delta_{\mathrm{C}}: 12.8,14.6,22.6$, 48.7, 48.8, 49.0, 56.7, 57.2, 57.4, 98.3, 101.3, 105.9, 106.2, 112.8, 124.4, 139.9, 141.2, 143.8, 146.5, 146.9, 148.4, 153.0. Calcd. for $\mathrm{C}_{22} \mathrm{H}_{26} \mathrm{O}_{5} \mathrm{C}$ 71.33, $\mathrm{H}$ 7.07; found $\mathrm{C}$ 71.12, $\mathrm{H}$ 7.10.

r-1-Ethyl-c-2-methyl-t-3-(2,4,5-trimethoxyphenyl)-5,6-dimethoxyindane (14). General procedure was carried out using alcohol 13 (0.090 g, $0.464 \mathrm{mmol})$, styrene 1 (0.104 g, $0.5 \mathrm{mmol}$ ) and $\mathrm{SnCl}_{4}$ (0.156 g, $0.3 \mathrm{mmol}$ ) afforded 14 as an oil (0.149 g, 84\%).

NMR data: $\delta_{\mathrm{H}}: 0.96\left(3 \mathrm{H}, \mathrm{t}, \mathrm{J}: 7.4 \mathrm{~Hz}, \mathrm{CH}_{2} \mathrm{CH}_{3}\right), 1.02\left(3 \mathrm{H}, \mathrm{d}, \mathrm{J}: 7.2 \mathrm{~Hz}, \mathrm{CHCH}_{3}\right), 1.55$ (1H, m, J: 7.4, 7.7 and $\left.13.6 \mathrm{~Hz}, \mathrm{CH}_{2} \mathrm{CH}_{3}\right), 1.75\left(1 \mathrm{H}, \mathrm{m}, \mathrm{J}:\right.$ 6.9, 7.4 and $\left.13.6 \mathrm{~Hz}, \mathrm{CH}_{2} \mathrm{CH}_{3}\right), 2.43(1 \mathrm{H}, \mathrm{m}, \mathrm{J}$ : 6.9, 7.2 and $\left.7.9 \mathrm{~Hz}, \mathrm{CHCH}_{3}\right), 2.91\left(1 \mathrm{H}, \mathrm{m}, \mathrm{CHCH}_{2}\right), 3.65\left(3 \mathrm{H}, \mathrm{s}, \mathrm{OCH}_{3}\right), 3.74\left(3 \mathrm{H}, \mathrm{s}, \mathrm{OCH}_{3}\right)$, $3.84\left(3 \mathrm{H}, \mathrm{s}, \mathrm{OCH}_{3}\right), 3.90\left(3 \mathrm{H}, \mathrm{s}, \mathrm{OCH}_{3}\right), 3.91\left(3 \mathrm{H}, \mathrm{s}, \mathrm{OCH}_{3}\right), 4.33$ (1H, d, J: $\left.7.9 \mathrm{~Hz}, \mathrm{CHAr}\right), 6.38$ $(1 \mathrm{H}, \mathrm{s}, \mathrm{Ar}), 6.45(1 \mathrm{H}, \mathrm{s}, \mathrm{Ar}), 6.59(1 \mathrm{H}, \mathrm{s}, \mathrm{Ar}), 6.79(1 \mathrm{H}, \mathrm{s}, \mathrm{Ar}) . \delta_{\mathrm{C}}: 12.9,14.7,22.7,48.9,49.0$, 49.5, 56.6, 56.7, 56.8, 57.2, 57.4, 98.4, 108.7, 108.8, 112.9, 124.9, 138.6, 140.2, 143.8, 148.2,148.4,148.6,153.0. Calcd. for $\mathrm{C}_{23} \mathrm{H}_{30} \mathrm{O}_{5} \mathrm{C} 71.48, \mathrm{H}$ 7.82; found C 71.35, H 7.85.

r-1-Ethyl-c-2-methyl-t-3-(2,4,5-trimethoxyphenyl)-4,5,6-trimethoxyindane (15). General procedure was carried out using alcohol 11 (0.104 g, $0.464 \mathrm{mmol})$, styrene 1 (0.112 g, $0.54 \mathrm{mmol})$ and $\mathrm{SnCl}_{4}$ (0.156 g, $0.3 \mathrm{mmol})$ afforded 15 as an oil (0.187 g, 98\%). NMR data: $\delta_{\mathrm{H}}: 0.95$ (3H, t, J: $7.4 \mathrm{~Hz}$, $\mathrm{CH}_{2} \mathrm{CH}_{3}$ ), 0.97 (3H, d, J: $\left.6.9 \mathrm{~Hz}, \mathrm{CHCH}_{3}\right), 1.54$ (1H, m, J: 6.1, 7.2 and $\left.13.3 \mathrm{~Hz}, \mathrm{CH}_{2} \mathrm{CH}_{3}\right), 1.73$ $\left(1 \mathrm{H}, \mathrm{m}, \mathrm{J}: 6.1,7.2\right.$ and $\left.13.3 \mathrm{~Hz}, \mathrm{CH}_{2} \mathrm{CH}_{3}\right), 2.36\left(1 \mathrm{H}, \mathrm{m}, \mathrm{J}: 3.6,6.9\right.$ and $\left.7.2 \mathrm{~Hz}, \mathrm{CHCH}_{3}\right), 2.93$ $\left(1 \mathrm{H}, \mathrm{m}, \mathrm{CHCH}_{2}\right), 3.54\left(3 \mathrm{H}, \mathrm{s}, \mathrm{OCH}_{3}\right), 3.58\left(3 \mathrm{H}, \mathrm{s}, \mathrm{OCH}_{3}\right), 3.81\left(3 \mathrm{H}, \mathrm{s}, \mathrm{OCH}_{3}\right), 3.87(6 \mathrm{H}, \mathrm{s}$, $\left.\mathrm{OCH}_{3}\right), 3.88\left(3 \mathrm{H}, \mathrm{s}, \mathrm{OCH}_{3}\right), 4.33(1 \mathrm{H}, \mathrm{d}, \mathrm{J}: 3.6 \mathrm{~Hz}, \mathrm{CHAr}), 6.15(1 \mathrm{H}, \mathrm{s}, \mathrm{Ar}), 6.56(2 \mathrm{H}, \mathrm{s}, \mathrm{Ar}) . \delta_{\mathrm{C}}$ : 12.9, 15.3, 22.0, 46.6, 48.2, 48.5, 56.6, 57.2, 57.2, 60.7, 61.4, 98.2, 103.5, 112.5, 125.3, 129.6, 141.0, 143.1, 143.8, 148.2, 150.9, 152.0, 153.5. Calcd. for $\mathrm{C}_{24} \mathrm{H}_{32} \mathrm{O}_{6} \mathrm{C} 69.21, \mathrm{H}$ 7.74; found C 69.15, H 7.78.

r-1-Ethyl-t-2-methyl-c-3-(4-methoxyphenyl)-4,5,7-trimethoxyindane (17). General procedure was carried out using alcohol $3(0.050 \mathrm{~g}, 0.22 \mathrm{mmol})$, styrene 16 (0.037 g, $0.25 \mathrm{mmol})$ and $\mathrm{SnCl}_{4}$ $(0.074 \mathrm{~g}, 0.28 \mathrm{mmol})$ afforded by p-tlc $\left(\mathrm{CH}_{2} \mathrm{Cl}_{2}\right) 17$ as white solid, mp: $82-84{ }^{\circ} \mathrm{C}(0.0315 \mathrm{~g}$, 41\%).

NMR data: $\delta_{\mathrm{H}}: 0.91\left(3 \mathrm{H}, \mathrm{t}, J: 7.5 \mathrm{~Hz}, \mathrm{CH}_{2} \mathrm{CH}_{3}\right), 1.19\left(3 \mathrm{H}, \mathrm{d}, J: 6.9 \mathrm{~Hz}, \mathrm{CHCH}_{3}\right), 1.63(1 \mathrm{H}, \mathrm{m}$, 
$\left.\mathrm{CH}_{2} \mathrm{CH}_{3}\right), 1.94$ (1H, m, J: 3.3, 7.5 and $\left.14.9 \mathrm{~Hz}, \mathrm{CH}_{2} \mathrm{CH}_{3}\right), 2.12(1 \mathrm{H}, \mathrm{m}, \mathrm{J}:$ 5.3, 5.5 and $6.9 \mathrm{~Hz}$, $\left.\mathrm{CHCH}_{3}\right), 2.75\left(1 \mathrm{H}, \mathrm{m}, \mathrm{J}\right.$ : 3.3, 5.5 and $\left.8.6 \mathrm{~Hz}, \mathrm{CHCH}_{2}\right), 3.25\left(3 \mathrm{H}, \mathrm{s}, \mathrm{OCH}_{3}\right), 3.80\left(3 \mathrm{H}, \mathrm{s}, \mathrm{OCH}_{3}\right)$, $3.85\left(3 \mathrm{H}, \mathrm{s}, \mathrm{OCH}_{3}\right), 3.86\left(3 \mathrm{H}, \mathrm{s}, \mathrm{OCH}_{3}\right), 3.88$ (1H, d, J: $\left.5.3 \mathrm{~Hz}, \mathrm{CHAr}\right), 6.44(1 \mathrm{H}, \mathrm{s}, \mathrm{Ar}), 6.84$ (2H, d, J: 8.8, Ar), 7.09 (2H, d, J: 8.8, Ar). $\delta_{\mathrm{C}}: 12.1,22.0,26.8,49.6,52.9$, 55.8, 56.2, 57.1, 57.5, 60.4, 97.5, 114.1, 127.5, 129.3, 139.5, 140.3, 140.5, 152.8, 152.9, 158.3. Calcd. for $\mathrm{C}_{22} \mathrm{H}_{28} \mathrm{O}_{4} \mathrm{C}$ 74.13, H 7.92; found C 73.95, H 7.83.

r-1-Ethyl-c-2-methyl-t-3-(4-methoxyphenyl)-4,5,6-trimethoxyindane (18). General procedure was carried out using alcohol 11 (0.113 g, $0.5 \mathrm{mmol})$, styrene 16 (0.074 g, $0.5 \mathrm{mmol})$ and $\mathrm{SnCl}_{4}$ (0.166 g, $0.64 \mathrm{mmol})$. Afforded by p-tlc $\left(\mathrm{CH}_{2} \mathrm{Cl}_{2}\right) 18$ as clear oil. (0.0935 g, 53\%).

NMR data: $\delta_{\mathrm{H}}: 0.98\left(3 \mathrm{H}, \mathrm{t}, \mathrm{J}: 7.4 \mathrm{~Hz}, \mathrm{CH}_{2} \mathrm{CH}_{3}\right), 1.02\left(3 \mathrm{H}, \mathrm{d}, \mathrm{J}: 7.1 \mathrm{~Hz}, \mathrm{CHCH}_{3}\right), 1.62$ (2H, m, $\left.\mathrm{CH}_{2} \mathrm{CH}_{3}\right), 2.47\left(1 \mathrm{H}, \mathrm{m}, \mathrm{J}: 5.3,7.1\right.$ and $\left.7.1 \mathrm{~Hz}, \mathrm{CHCH}_{3}\right), 3.04\left(1 \mathrm{H}, \mathrm{m}, \mathrm{CHCH}_{2}\right), 3.47(3 \mathrm{H}, \mathrm{s}$, $\left.\mathrm{OCH}_{3}\right), 3.80\left(3 \mathrm{H}, \mathrm{s}, \mathrm{OCH}_{3}\right), 3.83\left(3 \mathrm{H}, \mathrm{s}, \mathrm{OCH}_{3}\right), 3.90\left(3 \mathrm{H}, \mathrm{s}, \mathrm{OCH}_{3}\right), 3.95(1 \mathrm{H}, \mathrm{d}, \mathrm{J}: 5.1 \mathrm{~Hz}$, CHAr), 6.59 (1H, s, Ar), 6.82 (2H, d, J: $8.8 \mathrm{~Hz}, \mathrm{Ar}), 7.03$ (2H, d, J: $8.8 \mathrm{~Hz}, \mathrm{Ar}) . \delta_{\mathrm{C}}:$ 12.9, 15.2, 22.5, 48.4, 48.7, 55.4, 55.7, 56.7, 60.7, 61.4, 103.9, 114.0, 129.0, 130.5, 137.5, 141.3, 143.4, 150.9, 153.6, 158.4. Calcd. for $\mathrm{C}_{22} \mathrm{H}_{28} \mathrm{O}_{4} \mathrm{C} 74.13$, H 7.92; found C 74.35, H 7.80.

r-1-Ethyl-c-2-methyl-t-3-(4-methoxyphenyl)-5,6-dimethoxyindane (19). General procedure was carried out using alcohol 13 (0.098 g, $0.5 \mathrm{mmol})$, styrene 16 (0.074 g, $0.5 \mathrm{mmol})$ and $\mathrm{SnCl}_{4}$ (0.166 g, $0.64 \mathrm{mmol})$. Afforded by p-tlc $\left(\mathrm{CH}_{2} \mathrm{Cl}_{2}\right) 19$ as clear oil (0.090 g, 55\%).

NMR data: $\delta_{\mathrm{H}}: 1.00\left(3 \mathrm{H}, \mathrm{t}, \mathrm{J}: 7.3 \mathrm{~Hz}, \mathrm{CH}_{2} \mathrm{CH}_{3}\right), 1.06\left(3 \mathrm{H}, \mathrm{d}, \mathrm{J}: 7.1 \mathrm{~Hz}, \mathrm{CHCH}_{3}\right), 1.42$ (1H, m, J: 7.3, 8.9 and $\left.14.7 \mathrm{~Hz}, \mathrm{CH}_{2} \mathrm{CH}_{3}\right), 1.73\left(1 \mathrm{H}, \mathrm{m}, \mathrm{J}: 5.9,7.3\right.$ and $\left.14.9 \mathrm{~Hz}, \mathrm{CH}_{2} \mathrm{CH}_{3}\right), 2.47(1 \mathrm{H}, \mathrm{m}, \mathrm{J}$ : 7.1, 7.1 and $\left.9.1 \mathrm{~Hz}, \mathrm{CHCH}_{3}\right), 2.95\left(1 \mathrm{H}, \mathrm{m}, \mathrm{J}: 5.9,7.1\right.$ and $\left.8.9 \mathrm{~Hz}, \mathrm{CHCH}_{2}\right), 3.75\left(3 \mathrm{H}, \mathrm{s}, \mathrm{OCH}_{3}\right)$, $3.84\left(4 \mathrm{H}, \mathrm{OCH}_{3}\right.$ and $\left.\mathrm{CHAr}\right), 3.92\left(3 \mathrm{H}, \mathrm{s}, \mathrm{OCH}_{3}\right), 6.44(1 \mathrm{H}, \mathrm{s}, \mathrm{Ar}), 6.83(1 \mathrm{H}, \mathrm{s}, \mathrm{Ar}), 6.88(2 \mathrm{H}, \mathrm{d}$, J: $8.6 \mathrm{~Hz}, \mathrm{Ar}), 7.09(2 \mathrm{H}, \mathrm{d}, \mathrm{J}: 8.9 \mathrm{~Hz}, \mathrm{Ar}) . \delta_{\mathrm{C}}\left(\mathrm{CDCl}_{3}\right): 12.9,14.3,23.0,49.1,50.3,55.8,56.6$, 56.7, 57.1, 108.6, 108.7, 114.3, 130.0, 136.8, 138.8, 140.0, 148.2, 148.7, 158.7. Calcd. for $\mathrm{C}_{21} \mathrm{H}_{26} \mathrm{O}_{3} \mathrm{C}$ 77.27, $\mathrm{H}$ 8.03; found C 77.31, H 7.95.

\section{Acknowledgements}

This work was supported financially by Grants TB50 UBA and B 083 UBA.

\section{References}

1. Guanawardena, Y.A.G.P.; Sotheeswaran, S.; Sultanbawa, M.U.S.; Surendrakumar, S.; Blandon, P. Phytochemistry 1986, 25, 1498.

2. Saxena, B.P.; Koul, O.; Tikku, K.; Atal, C.K. Nature 1977, 270, 512.

3. Nagle, G.D.; Zhou, Y.D.; Park, P.U.; Paul, V.J.; Rajbhandari, I; Duncan, C.J.D.; Pasco, D.S. J. Nat. Prod. 2000, 63, 1431.

4. Saxena, D.B. Phytochemistry 1986, 25, 553. 
5. Jasicka-Misiak, I.; Lipok, J.; Moliszewska, E. Chem. Inz. Ekol. 1999, 6 (2-3), 149.

6. Zanoli, P.; Avallone, R.; Baraldi, M. Phytother. Res. 1998, 12 (1) S114.

7. Lemini, C.; Mandoki, J.J.; Cruz-Almanza, R.A.; Toscano; R. Cryst. Struct. Commun. 1990, C46 (8), 1542.

8. MacMillan, J.; Martin, I.L.; Morris, D.J. Tetrahedron 1969, 25, 905.

9. Alesso, E.N.; Tombari, D.G.; Moltrasio, G.Y.; Aguirre, J.M. Can. J. Chem. 1987, 65, 2568.

10. Alesso, E.N.; Torviso, R.; Erlich, M.; Finkielstein, L.M.; Lantaño, B.; Moltrasio, G.Y.; Aguirre, J.M.; Vázquez, P.; Pizzio, L.; Cáceres, C.; Blanco, M.; Thomas, H. Synthetic Commun. 2002, 32 (24), 3812.

11. Angle, S.R.; Arnaiz, D. O. J. Org. Chem. 1992, 57, 5937.

12. Lantaño, B.; Aguirre, J.M.; Finkielsztein, L.M.; Alesso, E.N.; Brunet, E.; Moltrasio, G.Y. Synthetic Commun. in press.

13. Alesso, E.N.; Moltrasio, G.Y.; Mufato, J.D.; Aguirre, J.M. Aust. J. Chem. 1992, 45, 1753.

14. Al-Farhan, E.; Keehn, P.M.; Stevenson, R. J. Chem Res., Synop. 1992, 36.

15. Patra, A.; Mitra, A.K. J. Nat. Prod. 1981, 44, 668.

16. Kursanov, D.N.; Parnes, Z.N.; Loim, N.M. Synthesis 1974, 633.

17. Dewar, M.J.S.; Zoebisch, E.; Healy, E.G.; Stewart, J.J.P. J. Am. Chem. Soc. 1985, 107, 3902.

18. Sharma, P.K.; Dandiya, P.C. Indian Journal of Applied Chemistry 1969, 32, 326.

19. Feugeas, C. Bull. Soc. Chim. France 1964, 8, 1892.

20. Cook, J.W.; Johnston, T.Y.; Loudon, J.D. J. Chem. Soc. 1950, 537.

21. Muller, S.; Raltschewa, M.; Papp, M. Ber. 1942, 75B, 692. 